\title{
Chapter 9 \\ Whom Is the National Curriculum for? \\ Politics in the National Curriculum System of South Korea
}

\author{
Kyunghee So
}

\subsection{Introduction}

Many countries around the world have implemented education policies in which the central government prescribes a curriculum for schools and teachers to follow. Such policies are rooted in the growing recognition that curricula should play a stronger role in influencing and improving teachers' practice. Policymakers understand that students' educational achievements are related more directly to teaching than to any other factor; as a result, the policymakers have increasingly focused on developing curricula to influence teaching (Sinnema and Aitken 2013). The pace of introduction of state-led curriculum policies has increased since 2000, when the OECD initiated international comparisons of student educational achievements through the Programme for International Student Assessment (PISA). Global competition triggered by PISA, has highlighted the need for quality management of school education at the national level; this has led many countries to introduce a national curriculum system based on which schools, teachers, and classes are controlled. Therefore, in various countries, the national curriculum is now becoming a key leverage point in improving education; policymakers seek to improve education by controlling the curriculum at the national level.

The top-down curriculum policies implemented in many countries aim to provide a better, more equitable education for all students. This hope has been strengthened by the PISA-recorded outstanding educational achievements of East Asian countries, such as Korea, Hong Kong, and Singapore, which have long had national curricula. Following the United Kingdom, which introduced the national curriculum system in 1988, English-speaking countries, such as Australia and New Zealand, have also adopted this system. The United States has also developed the Common Core Standards at the federal level; schools and teachers in all 50 states are required

\footnotetext{
K. So $(\bowtie)$

Department of Education, Seoul National University, Seoul, South Korea

e-mail: sohee@snu.ac.kr 
to follow these guidelines. However, the national curriculum model in which the central government prescribes curricular content and teaching methods in detail has been strongly criticized for forcing teachers to become technicians, carrying out a predefined process (Masuda 2010; Priestley and Biesta 2013; Taylor 2013).

Recent discourses affecting world education policy have emphasized the role of teachers (OECD 2005; Barber and Mourshed 2007). Countries with national curriculum systems have kept pace with this trend, reducing the amount of content prescribed at the national level and developing policies that increase school-level autonomy, which allows educators to make decisions about the curriculum (Sinnema and Aitken 2013). This is a crucial change, which deviates from the policy direction of the past that de-professionalized teachers through prescriptive curricula and strict control (Priestley and Biesta 2013). This new form of national curriculum policy reduces detailed government instructions on educational content and methods, allowing teachers to become active developers of the curriculum (Priestley 2011). This change is evident from the frequent use of rhetoric that emphasizes the autonomy of teachers and projects them as agents of change in the national curriculum policies. However, as these new policies also include gradually expanding systems of accountability, there is controversy over whether the new approach really guarantees teachers any more autonomy than the previous prescriptive approach. While detailed government-led curricular prescriptions are disappearing in many countries, efforts to replace them by control over educational output have increased (Priestley et al. 2015).

South Korea has witnessed several revisions to its national curriculum system since its introduction in the 1950s; thus, a rich discourse on the national curriculum system exists. South Korea faced difficulties in designing and developing modern education owing to Japanese colonial rule for 35 years in the early twentieth century, 3 years of US military administration after liberation in 1945, and the Korean War from 1950 to 1953. Since the Korean War, however, South Korea has achieved rapid educational growth in a short period of time; it has been consistently ranked at the top in all areas monitored by PISA since 2000 (So and Kang 2014a). The national curriculum has played a crucial role in enabling South Korea to achieve such remarkable educational results in a short period of time. Introduced after the Korean War, the national curriculum stipulates guidelines on every subject that is taught during the 12 years of elementary, middle, and high school, setting the content and class hours for each subject. As the national curriculum has powerful legal authority, public and private schools and teachers in all regions have to follow the government guidelines. The long-established national curriculum system has provided a common set of standards for school education, guaranteeing equal educational conditions for all students across South Korea and helping to improve their educational achievements.

In the early days, the national curriculum documents contained highly detailed prescriptions for educational content, leaving schools and teachers with little flexibility or autonomy to make decisions about the curriculum. The education policy first began to change in the early 1990s, when the government implemented an autonomy policy that gradually gave regions and schools the discretion to make 
decisions about the curriculum. There have recently been efforts to reform the curriculum to overcome a school culture focused on college entrance examinations (associated with the chronic ills of Korean education) in order to increase student happiness and well-being. This proposed change highlights a policy discourse that calls on teachers to be agents of change. However, despite several revisions of the national curriculum to improve school performance, there has actually been little change in schools. The issue of reform without change (Cuban 1988; Spillane 1999; Tyack and Cuban 1995) is becoming a point of controversy in South Korean society as in other countries.

Education policy reflects the values and intentions of policymakers, not only providing the means to govern the actual actors of education, but also influencing their thoughts and behaviors (Grimaldi 2012; Popkewitz 1991). In particular, the national curriculum exerts diverse and subtle forms of influence over school settings because the framework itself is seen as constraining teachers (Ball 2006). South Korea has had a national curriculum system for many years; the national curriculum has been constantly revised in various historical and social contexts, maintaining a powerful influence over schools and teachers. A review of South Korea's national curriculum system can help us understand how tension and controversy work around the national curriculum and how the system can influence schools.

This study aims to provide insight into the complicated and sometimes contradictory role of the national curriculum and its impact on actual school settings by reviewing South Korea's national curriculum reform process over the last 60 years. To this end, the present study focuses on the following two topics. First, it reveals the politics of national curriculum reform by providing historical-sociological explanations of South Korea's national curriculum reform. Second, it explores how the national curriculum system influences school education.

\subsection{The Changing National Curriculum Policy}

As curricular reform is highly contextual and often political, it is always tailored to the society, culture, and education system of the country in which it occurs. The South Korean national curriculum was established in a unique historical and social context; it has been revised every time there has been a change in political power. Korea had a ruling dynasty until the early twentieth century and was ruled by Japan from 1910 to 1945. After liberation, South Korea officially formed the government of the Republic of Korea in 1948 and established a national curriculum system. Initially, the South Korean national curriculum focused on forming a nation with a unique South Korean identity, using a curriculum strictly laid out by the central government. However, since the establishment of a civilian government in the 1990s, the national curriculum has promoted a more autonomous and diversified style of education. The recently revised national curriculum argues that the happiness of students is the nation's top educational priority. The following section provides historical-sociological explanations of these changes to the Korean national curriculum. 


\subsubsection{Forming an Intrinsic Identity as Koreans: Building the Nation as a Homogeneous Group}

With its liberation from Japanese rule in 1945, Korea was divided into South and North, under the military administrations of the US and the Soviet Union, respectively. During its 3 years of military administration, the US aimed to imprint its own democratic ideology and system on South Korean society. The US military authorities led educational reforms, with the cooperation of the Korean education authorities. As a result, the foundation for the current school system (six years of elementary school, three years of middle school, three years of high school, and four years of university) and the compulsory education system was established. The period of US military administration also served as a momentum for South Korean education to proactively introduce and accept US educational ideas. Some scholars developed the so-called "New Education Movement" under the influence of US progressivism, which helped to introduce a child- and life-centered curriculum to the school setting. In particular, during this period, the "syllabus," a set of guidelines to be followed by South Korean schools, was provided, and it became the foundation upon which South Korea could later establish its own national curriculum system (So et al. 2012).

The rule of the US military administration was terminated with the official establishment of the South Korean government in 1948. The Education Act, enacted in 1949, gave the new government the authority to implement an independent and democratic system of education. However, the Korean War broke out in 1950 and lasted until 1953, when South and North Korea reached an armistice agreement. South Korea's most important postwar education policy was to make elementary school compulsory. This policy was based on the ideological conviction that education was a major driving force of national development. It quickly had an effect. By the 1960s and 1970s, South Korea had achieved complete school attendance, not only in elementary school but also in middle school (Park 2015). Another meaningful postwar event was the establishment of a national curriculum to regulate all schools in South Korea. As a result, South Korea came to have a single standardized curriculum, based on the standards by which all schools and students nationwide were efficiently controlled.

The national curriculum initially emphasized nation-building. The 1948 constitution stated that the nation was the source of political agency in South Korea. However, actual nation-building was achieved through the national curriculum. As a nation consists of members of a specific country, it is very important for those members to form a shared national identity. A nation's most critical requirement is to have active subjects who perceive themselves to be members of the country and who voluntarily participate in various activities of the country (Hwang 2015). Since development of nationhood was a very complicated, long-term process, it was inevitable that the government would apply some legal force. The national curriculum was a key mechanism for shaping the national identity of children and adolescents. The national curriculum was designed to have two types of agency: political and 
economic. Politically, the curriculum aimed to develop obedient citizens who were voluntarily and actively devoted to the country; economically, its goal was to produce efficient, productive citizens to vitalize the national economy (Hwang 2015).

The policy most extensively implemented through the 1950s' national curriculum aimed to develop political agents through moral education. Resistance to American-style liberal values from the US military administration period as well as the cold war between South and North Korea generated a desperate need for a system of education that promoted national identity and collective ethics. For this reason, the first national curriculum, established in 1954, emphasized moral education; since that time, this aspect of the curriculum has been strengthened, evolving into an independent subject called "ethics" that remains part of the curriculum today. Moral education included democracy as well as nationalist ethics and anticommunist education. However, democracy was presented as an ideology opposed to communism in the confrontation with North Korea as well as a fundamental political ideology of the state; it was thus quite different from American democracy. Moral education used the ethics of nationalism and collectivism to redefine democracy by attempting to deny individuals their own agency as individuals and forcing them into a group. Moral education was an educational plan designed to form a collective nation.

The attempt to make the nation an obedient political subject through the national curriculum was accelerated when a military government was established, following the military revolution of 1961 . This government tried to emphasize the distinct identity of Koreans by incorporating national ideological training into the school curriculum. National ideological training included anticommunist education, which emphasized the hostile relationship with North Korea, and "Korean-style democracy," an interpretation of Western democracy that was adapted to the South Korean context (So et al. 2012). In particular, a Charter of National Education, incorporated into the school system in 1968, served as the basic text for forming the nation and shaping Korean identity. Korean history education, which was a mandatory subject from elementary to high school in the 1970s, also contributed to the nation-building through the organization of contents identifying the state with the nation.

The national curriculum was also used to turn the South Korean population into efficient economic agents. After the Korean War, vocational education and technical education were strengthened in order to revitalize the national economy, which was impoverished after years of war. During the 1960s, South Korea was in the midst of industrialization, and the principal role of education in this period was to provide the massive workforce needed to industrialize the country. However, despite this policy, Korea's leaders still felt that it was more important for the national curriculum to create a disciplined population motivated by nationalism than the rational economic agents required by modern capitalism (Hwang 2015). The government implemented its curriculum policy to let school edcuation help citizens acquire modern knowledge as well as develop disciplines needed to secure a workforce with a modern work ethic. While the national curriculum of that era was designed to nurture an efficient economic workforce, it emphasized disciplines and ethics used to tame citizens, so as to mobilize them to enact national policies. 
In short, South Korea's early national curriculum fostered obedient political agents, using nationalist education on the one hand, and tried to create efficient economic agents to drive modernization and industrialization, on the other. The national curriculum has played a role in nation-building, with an intricate emphasis on these two goals. The policy lasted until the 1980s, alongside the military government.

\subsubsection{Toward Autonomy and Democratization: Increased Autonomy for Schools and Teachers}

The technical form of the national curriculum can either improve the quality of all students' performance by determining the conditions in schools and classrooms or lower the quality of educational achievement by disrupting professionalism in schools and classrooms (So and Kang 2014a). In Korea, the guidelines set forth in national curriculum documents have violated the autonomy of schools and classrooms by strictly controlling the curriculum of all primary and secondary schools nationwide. The government has prescribed in detail the subjects to be taught during each year of school, the hours required for each subject, and all educational content. In the 1990s, the Korean national curriculum policy underwent a remarkable change. Korean society faced a huge turning point, following the democratization movement of June 1987. This democratization trend questioned the standardization of school curricula created by excessive government control of education. The revised national curriculum in 1992 attempted to provide each region and school with opportunities to make decisions about the curriculum. The establishment of "optional activities," creative educational activities that schools could organize on their own to meet unique educational needs or student demands, was a typical provision under this policy (Ministry of Education 1992).

The direction of Korea's national curriculum policy faced a qualitative change when a civilian government was established in 1993. The civilian government changed the direction of national education, focusing more on nurturing democratic citizens and breaking away from the nationalist, anticommunist ideology emphasized by the previous military governments. Given the rapid development of globalization since the 1990s, Korea's national curriculum has focused on fostering democratic citizens who are able to cope with globalization.

The Kim Young-sam government (1993-1998), Korea's first civilian government, established an education reform plan that was qualitatively different from those in the past. Specifically, it aimed to help Korea be part of globalization and informatization that characterize the twenty-first century (Commission for Education Reform 1995). In its "May 31 Educational Reform," carried out in 1995, the government established that the main direction for educational reforms would be liberalization and democratization. The government shifted its direction away from supplier-based one-way education toward a consumer-focused autonomous and 
open form of education. These educational reforms fully introduced neoliberalism to the field of education, indicating that an emphasis on regional- and schol-level autonomy and competition would replace the state-led standardized education of the past. The direction of these reforms provided a foundation for the revisions of national curriculum of the time and later. The revised national curriculum in 1997 promoted a "student-centered curriculum" that would replace uniformity with diversity in education. This curriculum focused on enabling schools to organize and adapt the curriculum to accommodate various aptitudes and levels of students (So 2017).

The subsequent Kim Dae-jung government (1998-2003) and Roh Moo-hyun government (2003-2008) also aimed to reform the national curriculum, based on the educational reform plan presented by the first civilian government. By making more changes to the national curriculum, these governments implemented policies that further empowered the regions and schools to make decisions about the curriculum. However, the curriculum autonomy policy took a new turn when the national curriculum was revised again in 2009, during the Lee Myung-bak government (2008-2013). This revised 2009 national curriculum included various guidelines that allowed schools to make decisions about many aspects of the curriculum. One example was the reduced number of prescribed actions, which previously imposed strict boundaries between each grade and subject. Instead, the new national curriculum enabled schools to autonomously determine how to organize their curricula by using a cluster system that combines several subjects or grades. In addition, under this new system, schools had the authority to increase or decrease $20 \%$ of the class hours required by the national curriculum. For high schools, the adoption of this new system of autonomy at the school level left many parts of the school curriculum to the professional judgment of teachers (Ministry of Education, Science, and Technology 2009). Through this series of curricular reforms, an institutional framework was established, enabling schools to exercise autonomy when making curricular decisions.

As discussed above, a series of national curricular reforms since the 1990s have focused on increasing the freedom of regions, schools, and teachers to make decisions about the curriculum. However, nation-building, which was the traditional role of the national curriculum, has not been completely discarded. The traditional aims of the curriculum have remained the same, but the definition of "a good citizen" has changed over time. Civilian governments wanted their citizens to be autonomous, competitive, and able to engage proactively in globalization, rather than strongly nationalist or anticommunist. Such citizens could not be created through one-way government control as in the past, but had to be developed within an autonomous atmosphere. The national curriculum of civilian governments, therefore, emphasized competitive, competent economic agency, rather than political agency within a nationalist group (Hwang 2015). The political agency emphasized by the military-government curriculum were undermined by the democratization process; civilian governments aimed to foster citizens with economic capacity to thrive in the so-called age of limitless competition. Thus, the national curriculum changed direction, from building the nation that would obey its 
leaders to developing competent individuals contributing to an increase in national competitiveness. Curriculum policies from the civilian governments, which gradually increased the autonomy of regions and schools in curricular decision-making, provided an essential foundation for educating people who would thrive in a market economy.

\subsubsection{Putting Students' Happiness at the Center of School Education: Emphasizing Student Agency}

Once PISA began to carry out comparative international research to assess student achievement, many countries began to focus on increasing their own students' academic excellence. The USA, which was ranked lower than East Asian countries such as Korea, Singapore, and Hong Kong in terms of academic achievement, has recently sought to implement a national standard for several subject matters (Zhao 2009). However, despite these efforts by the US federal government, American culture remains less obsessed with easily measured results, such as test scores (McCluskey 2010). As a result, despite a relatively low PISA ranking, Americans show higher happiness levels than citizens from the countries ranked higher than the USA (OECD 2011).

In Korea, the opposite is the case. Despite an enviably high PISA ranking, the student happiness level is always at the bottom of the OECD countries (Park et al. 2010). This shocking result has forced Korean education policy to focus more on student happiness than academic achievement. The Park Geun-hye government (2013-2017) launched a new education vision with a policy that aimed to provide "happy education" helping students find their dreams and talents. Thus, the revised national curriculum in 2015 shifted the paradigm of education from "knowledgebased education" to "happy education" where students enjoy learning. The government adopted two approaches to helping students build happy lives: finding and eliminating the causes of student unhappiness, and actively providing students with opportunities to be happy (So and Kang 2014a). This policy stance has remained in place during the current government (2017-present).

Since 1998, Korea has used a standardized test to diagnose students' academic achievement at the national level. The test is carried out by sampling $1-5 \%$ of students in sixth grade (the sixth year in elementary school), ninth grade (the third year of middle school), and tenth grade (the first year of high school) across the nation. Five subjects are assessed: Korean, English, mathematics, social studies, and science. In 2008, the government expanded its sample to include all students in these grades to reduce the number of students who were ranked lower than the basic level of achievement. As a result, the ratio of students below the basic level has consistently decreased; the gap between cities and rural areas has also been reduced. Despite these positive effects, however, overheated competition among regions and schools over the results has resulted in students' increased stress and heavy workload. 
After this problem became a social issue, the Korean government made an effort to lessen the burden on students. In 2010, the standardized test started to be taken by second-year high school students instead of first-year students; the number of subjects was reduced from five to three (Korean, English, and mathematics). Elementary schools have been excluded from the standardized test since 2013 (Ministry of Education 2013a). In 2017, the current government drastically change the policy of the standardized test, leaving it up to each city and province to decide whether to carry out the test in middle and high schools. Accordingly, the local education office of each city or province can autonomously decide whether or not to carry out the test. The government samples only $3 \%$ of students, analyzes their results, and uses them to establish national education policies. This reform has been carried out despite some concerns that it could cause a decline in academic performance; it clearly demonstrates that the focus of Korea's education policy is directed toward student happiness.

To further relieve student stress, efforts are constantly being made to reduce the amount of learning content and workload required by the national curriculum. Students in Korea continue to be ranked high in every subject in international student assessments, including Trends in International Mathematics, Science Study (TIMSS), and PISA. However, behind such achievements lies the chronic issue of students suffering from extreme mental pressure due to the excessive burden of studying (So and Kang 2014a). This issue has been raised since the 1980s. Student stress is clearly caused by the excessive amount of academic content included in the national curriculum and high level of difficulty of many subjects (Shin et al. 1981). Therefore, efforts have been made to reduce the number of subjects that students are required to complete during the compulsory education period, as well as the number of hours required for each subject.

Despite all these changes, the heavy workload has continued to be cited as the main challenge to overcome throughout several revisions of the national curriculum. A wide range of policies have been implemented to resolve this issue. Every time the curriculum was revised, new policies were introduced, which include reducing the number of subjects that students take, empowering students to choose their own subjects in accordance with their own needs and abilities, reducing academic content in each subject, and carrying forward overly difficult content to the next year's program. The most recently revised national curriculum of 2015 is intended to reduce academic pressure on students by carefully selecting and reducing learning content while focusing on the key concepts that must be learned in each subject.

In addition, the Park Geun-hye government implemented a new policy called the "exam-free semester" to help students pursue a happy life. According to this policy, during one semester of middle school, teachers are given the flexibility to make their classes more student-centered by organizing debates or practical training but not organizing traditional exams. Students are also given a better chance to discover their dreams and talents by participating in various events, including career exploration activities (Ministry of Education 2013b). The exam-free semester was designed to change Korean education into a system that could develop student dreams and 
talents. It grew from an awareness that students had low levels of interest, confidence, and happiness because they faced extremely fierce competition in an education system focused on college entrance exams. The exam-free semester was implemented to address these chronic issues in Korean education and to achieve a breakthrough in public education. Some middle schools introduced the exam-free semester on an experimental basis in 2013; all middle schools have offered it since 2016.

The most distinctive feature of the exam-free semester is that students have no regular written exams. Instead, they can participate in and experience various activities during this semester. It is a remarkable change that schools have been willing to give up exams in an education system focused on college entrance. In the past, schools focused exclusively on preparing their students for the college entrance exams. As a result, the students had no chance to explore things they liked or wanted to do; teachers also found it difficult to provide autonomous and creative classes. The 2015 national curriculum reorganized middle-school education, enabling schools to operate flexibly enough to guarantee an exam-free semester. During this semester, teachers can autonomously replace some class hours with experiencebased activities that introduce students to different career paths, new academic topics, arts and sports, and club activities.

Previously, school education in Korea had forced students to learn "what was given" without considering their own aptitudes, interests, or needs. Teachers had to follow the national curriculum without their own judgments or interpretations. The exam-free semester is intended to fundamentally change the constitution of Korean school education. During this semester, teachers are expected to identify what their students want to do and to design and operate the curriculum based on their findings. The exam-free semester is a full-scale attempt to focus on developing student dreams and talents, which was previously overlooked in Korean education.

\subsection{Effects of the National Curriculum System on Actual School Education}

The Korean national curriculum has helped to provide equal educational conditions for students and to increase the educational achievements of all students by providing common standards for school education in Korea. The national curriculum has been frequently revised to provide better education. However, the massive reform of the national curriculum in Korea has not significantly changed actual school practice. Although Korea has established the basis for many changes by reforming the curriculum to ensure a more flexible, autonomous system of education that prioritizes student happiness, these reforms in reality have not been followed by actual changes. Despite reforms in the school education system, there has been little change in actual school practice. Analyzing the impact of the Korean national curriculum system on actual school practice can help to explain why. 


\subsubsection{Curriculum Reform for Government: Unchanged School Practice}

Curricular reforms are often political and policy-driven (Fernandez et al. 2008). Uniquely, the Korean national curriculum is revised whenever a new government comes to power. The revision is triggered by the political demands of new governments rather than by the educational demands from schools (Gim 2002). Since national curriculum revisions are accompanied by a 5-year-cycle of regime change, ironic situations - for example, a new curriculum being developed even before the previous one has been fully implemented in all schools-often ensue.

Korean national curriculum documents include both general guidelines and subject-specific curriculum. The general guidelines lay out the ideal human characteristics that the national curriculum should cultivate, goals for each school level, the subject organization for each grade, and the hours allocated to each subject. Each subject-matter curriculum includes specific content for each subject organized in the general guidelines. When a new national curriculum is developed, the general guidelines are developed first, followed by each subject-specific curriculum. Scholars who major in general education studies participate in developing the general guidelines, and subject specialists who major in specialized subjects develop each subject-specific curriculum. The new government always talks about reforming the field of education, and tries to put this rhetoric into practice in the form of education policy during its term in office. Thus, the national curriculum serves as a means of implementing political rhetoric. As a consequence, national curriculum revisions are always led by policymakers in a new government. These policymakers-for example, officials at Cheongwadae (the Blue House) or the Ministry of Education-determine the basic direction of and timing for the revision to actualize the new government's reform message. Scholars are then invited to develop the general guidelines in accordance with the policymakers' reform direction. The guidelines they develop are finalized through reviews and revisions by policymakers. Once this is done, each subject-matter curriculum is developed according to said guidelines. During this process, the creators of the general guidelines largely reflect the views of policymakers, forming a sort of hierarchical relationship with the subject specialists.

This "top-down" development process has generated conflicts between the general guidelines and subject-specific curriculum. This is one reason that national curricular reforms rarely lead to actual change in school settings. After a general framework is developed for the subject curriculum, subject specialists are then required to revise each curriculum according to the guidelines. However, although subject specialists seem to appropriately reflect the guidelines, they rarely make actual changes to their curriculum. For example, despite the fact that several governments have implemented a workload reduction policy for students, there has been little actual progress made in reducing learning content or adjusting levels of difficulty (So and Kang 2014b). The lack of change in actual school settings has created repetitive rhetoric: every new government comes up with a 
new way of reducing student workloads and reforming the curriculum. In other words, reforms have been constantly carried forward without any actual changes being made.

In fact, subject-specific curriculum have more impact on school practice in Korea than the general guidelines. Teachers of each subject depend almost entirely on the textbooks published by external specialists. The textbooks are based on subjectspecific curriculum developed by the government. Therefore, unless changes are made to such curriculum, there is almost no change in the quantity or quality of textbook content or any aspect of school education that depends solely on textbooks. Policymakers assume that, by reforming general guidelines, they will be able to influence the classes taught by teachers. (Cuban 2013). However, reforms that require teachers to change their classes are less likely to succeed than those affecting the structure of the school system only (Tyack 1991). Thus, revised general guidelines results in external changes to the school system but barely generate any real changes in actual classes.

The teachers themselves may be exhausted by the constant revisions to the national curriculum that are made by every new government. In Korea, promises to reform the national curriculum serve as political platforms for political leaders trying to win elections. The government's reform message typically disappears before being properly delivered to schools as the new government takes control. Sometimes a new message contradicts the old one. Given this pattern of political change, teachers stick to their own ways of teaching and wait for the government to be replaced, rather than enthusiastically responding to the reforms. Many teachers regard Korea's frequent reforms of the national curriculum as mere political plans implemented by the government for its own benefit (So 2013). In such a political maelstrom, teachers tend to stick to familiar approaches.

\subsubsection{Policy Attention Focused More on New Prescriptions Than on Enactment: Schools That Are Indifferent to Prescribed Duties}

The national curriculum is an "input-oriented" policy because it imposes a standard curriculum that all schools must adhere to. However, many Western countries that have adopted the national curriculum system have recently changed into controlling output rather than providing more detailed curricular measures (Priestley et al. 2015). Under the new policy, schools and teachers have the autonomy to make curriculum-related decisions but are responsible for their students' academic achievement that is measured through test-based accountability systems.

Through multiple revisions of the national curriculum, Korea has implemented a policy to reduce the government's curricular prescriptions. Regions and schools have been empowered to autonomously determine certain aspects of the curriculum. However, there are still many prescriptions from the national curriculum that are expected to be followed (Baek 2010; Hong 2011; Jeong and Lee 2011; Gim 2011). 
The 2015 national curriculum also details all required subjects for each year of primary and secondary school as well as class hours and educational content. Unlike trends in Western countries, in Korea, the test-based accountability system seems to be weakening; the national academic achievement test does not have much power to assess schools or teachers; and the results do not really control teaching practice. In recent years, individual cities and provinces have been able to decide on whether to take this test or not, further reducing influence of the test on actual classroom teaching.

In Korea, the national curriculum still has considerable power. The curriculum has legal authority to determine the status and content of subjects (Goodson 1994). Many stakeholders, therefore, focus on deciding what should be included in the national curriculum. Subject specialists fight to secure more hours and more academic content for their subjects. Various government departments and stakeholders struggle to incorporate their own interests into the national curriculum (So 2013). As a result, developing the national curriculum takes a great deal of time, effort, and funding, both to convey the government's reform rhetoric and to coordinate the demands of various stakeholders.

Recently, Korean curriculum policy has been heading in the direction of giving schools and regions more freedom to shape the curriculum. The national curriculum is expected to serve as the standard for regions and schools, enabling regional education offices and schoolteachers to develop more detailed versions. Hence, the government's ability to facilitate aligned yet context-sensitive local implementation is a crucial aspect of successful curriculum reform (Pietarinen et al. 2017). However, the Korean government has scant interest in how the new curriculum is enacted. Even though revised national curricula are expected to change and improve schools, the government does not really try to understand what is actually happening in schools. Policymakers and stakeholders are not interested in discussing or taking responsibility for implementing the changes described in national curriculum documents; their lack of interest stands in sharp contrast to the efforts that go into creating those documents.

Moreover, there are many cases in Korea in which national curriculum reforms failed to change the evaluation system. Students in Korea often begin to prepare for the college entrace examination from their early school years. Since high performance in the college entrance examination provides a condition for entering and graduating from top universities, which in turn helps to get a privileged job, students often study for getting into top universities from when they are young. Naturally, most schools provide classes geared toward the college entrance examination. This type of education explains why Korean students have such low levels of confidence, enjoyment, and happiness while learning, despite their high academic achievements (So and Kang 2014a). The national curriculum has been constantly revised to remove the evils of a college-entrance-exam-focused school education system; in fact, the 2015 national curriculum even claims to prioritize student "happiness." However, the college entrance examination still dominates school education. The system itself has not really changed in the direction suggested by national curriculum reforms. 
This may be why there is so little interest in implementing a new curriculum within the Korean system, in contrast to high interest in developing new prescriptions for the curriculum. This input-oriented system requires accountability through prescriptions rather than output. Both approaches, whether prescription- or outputoriented, deny teachers' adequate autonomy to make decisions about the curriculum. However, the Korean example shows that the prescription-oriented approach has more room for teacher autonomy than the output-oriented approach (Priestley et al. 2012). In a new-prescription-focused national curriculum system, few policymakers care how the prescribed curriculum is enacted by teachers or experienced by students. For this reason, Korean teachers do not react strongly to new reforms prescribed by the national curriculum. Instead, the college entrance examination actually controls both teachers' classes and students' lives, which is not intended by the government.

\subsubsection{Teachers Disciplined by the National Curriculum: The Absence of Teacher Agency}

Recent curriculum policies attempted in various countries around the world have referred to teachers as "agents of change." This policy trend aims to overcome the criticism that countless national curricular reforms have failed to introduce fundamental changes to actual school settings (Cuban 1988; Spillane 1999; Tyack and Cuban 1995). The repeated emptiness caused by "reform without change" has raised awareness of the importance of teachers' roles and capabilities in changing schools. Accordingly, many countries are working to reduce legal prescriptions and requirements in their national curricula, while simultaneously empowering schoollevel authorities to make decisions about the curriculum. Scotland has even made its national curriculum legally nonbinding, despite being a national framework, in order to emphasize school-level autonomy. The Scottish national curriculum provides much of its content in the form of guidelines; schoolteachers refer to these guidelines to develop their own curricula, reflecting the interests and learning needs of their students (Sinnema and Aitken 2013).

Since the 1990s, Korea has worked to minimize national control and to increase the power of regions and schools to make autonomous decisions about the curriculum. Korea currently allows regions and schools to autonomously adapt the curriculum to suit their own context, drawing on the guidelines developed by the central government (So 2017). By gradually increasing the teachers' authority to decide the content of the curriculum, the Korean government is presenting teachers as agents of change in educational reform. Teachers in Korea now have a certain power to change and adapt the curriculum.

However, although Korean teachers have the right to adapt the curriculum, they tend not to use this right. In Korea, the teaching profession guarantees a relatively high initial salary and a stable social status, which is why many outstanding academic candidates choose to teach (Barber and Mourshed 2007). However, these 
teachers, who were so competent when they were first appointed, become oddly passive in schools, rarely making full use of their expertise. The passivity of Korean teachers is closely related to the fact that Korea has maintained its national curriculum for such a long time (So and Kang 2014a). For teachers who were themselves educated within the national curriculum system, it seems natural to adhere to the prescribed national curriculum. Moreover, the subjects they teach are fully covered in assigned textbooks. For most Korean teachers, implementing the curriculum means teaching "by the textbook," which is often seen, not just as a learning aid, but as a "standard" or "Bible" to be strictly followed (Jeong 2006; Park 2007). In other words, the national curriculum has become a "closed text" that forces teachers to read in certain ways, rather than enabling them to interpret material or make autonomous decisions (Kim 2007). Within this national curriculum system, teachers have little room to display their expertise or design a creative curriculum.

In sum, Korea's long-standing national curriculum system has caused the professional lives of teachers to be disciplined by the national curriculum. The old school grammar that required teachers to follow the national curriculum to the letter forced them to constantly reflect on their teaching based on the national curriculum. Moreover, the unchanging textbook system, college entrance exam, and governmentimposed academic content all limit teachers' agency. Although their autonomy has increased in relation to the national curriculum, teachers disciplined by the national curriculum cannot easily discard conventional school rules or customs.

\subsection{Conclusion: The Remaining Challenge}

In the past few decades, Korea, like other Asian societies, has been through many social, economic, and political changes. Korea was democratized when its military regime was replaced by a civilian government. In response to the global pressure of neoliberalism, Korea has shown interest in nurturing autonomous and competent economic agents, rather than nationalist and collective political agents. The national curriculum has played a leading role in bringing these great changes to Korean society.

The Korean national curriculum, maintained for the past 60 years, has played a positive role in Korean education in some ways. Above all, the system has contributed to providing fair and equal educational opportunities to all students by being implemented in all schools nationwide. The national curriculum has recently been revised to meet the needs of different types of learners, showing that curricular reform can be used to improve equity in education (Sinnema and Aitken 2013). In addition, Korea's national curriculum has considerably helped teachers who feel uncertain or anxious about teaching by explicitly providing detailed content. Particularly for teachers grappling with large classes, a tough work environment, a lack of experience, or insufficient time to prepare for class, the national curriculum has served as an essential guide rather than a tool of pressure or control. In the long run, it has helped teachers to become skilled and well-informed (Apple 1988; Sloan 2006). 
Through multiple revisions of the national curriculum, Korea has established the foundations for a more flexible, teacher-driven approach to the curriculum, as well as forms of education that prioritize student happiness. However, massive reforms of the national curriculum have resulted in little actual change within schools. Although the system of school education has been reformed, actual school teaching has remained the same. This review challenges a few aspects of the national curriculum system in order to bring actual changes into schools.

First, it is necessary to adopt a strategy that interactively and dynamically uses both a top-down and bottom-up approach to school reform. School reform can be carried out in either way (Fullan 2007). In the top-down approach, schools and teachers are viewed as practitioners and consumers of the new curriculum developed by policymakers. By contrast, the bottom-up approach relies on school capabilities and the teaching community to create an innovative learning environment (Leana 2011; Lieberman and Pointer Mace 2008). Like Korea, many countries seek to change their education systems using the top-down approach. However, given that curricular reforms will not succeed unless teachers in school settings change themselves, this approach will not bring actual change to schools. Therefore, it is necessary to consider a strategy that integrates and draws on the strengths of both approaches (Fullan 1994; Hargreaves and Fullan 2012; Ramberg 2014). The new approach will need to provide the basic direction of and framework for school reform in the national curriculum while respecting and supporting the innovative efforts of school teachers.

Second, a shared sense-making process by stakeholders involved in school reform is required. Many school reform studies have shown that success of a reform is related to the way in which the reform is implemented (Priestley et al. 2015; Ramberg 2014). Korea tends to focus on prescribing new reforms rather than implementing them. However, no reform is likely to succeed without a clear understanding of how it will be carried out. Implementing curricular reform entails the translation of the new ideas into new educational practices. The process must involve all stakeholders working to implement the reform in shared sense-making (Hargreaves et al. 2009; Weick et al. 2005). The perceived meaning and significance of the curriculum reform will further guide the actions of the stakeholders involved in the process (Hargreaves et al. 2009). In other words, whether teachers accept or reject the reform is likely to be determined by its perceived meaning and significance. A massive reform of the curriculum cannot succeed in actual schools unless a collective effort is made to clarify and communicate the meaning and significance of the reform among stakeholders including school teachers.

Finally, we should focus on how best to create a structure that promotes teacher agency. Teacher agency refers to the power of teachers to actively and purposefully direct their own professional lives within structurally determined limits (Hilferty 2008). In other words, teacher agency is a pattern of practice or behavior actively adopted by teachers in response to a reform or policy imposed on them from the outside. In recent national curriculum policies, it is often suggested that teachers be 
given decision-making autonomy pertaining to the curriculum as a means to change school performance. However, autonomy is not the same as agency. Even if teachers have autonomy, they may fail to achieve agency if they reproduce past behavioral patterns out of habit. Korea has given teachers more autonomy to make decisions about the curriculum, but the teachers have not been proactive in making use of it. Teacher agency cannot be achieved merely by providing autonomy through reduced prescriptions or regulations. The surrounding structure or contextual conditions influence teacher agency (So and Choi 2018). In order to project teachers as real agents of change in schools, it is necessary that national curriculum policies focus on improving the structure and context in which teacher agency can be achieved.

\section{References}

Apple, M. (1988). Teachers and texts: A political economy of class and gender relations in education. New York and London: Routledge.

Baek, K. (2010). The elementary teachers' perception about the school-based curriculum autonomy. The Journal of Elementary Education, 23(2), 47-73.

Ball, S. J. (2006). Education and social class: The selected works of S.J. Ball. London: Routledge.

Barber, M., \& Mourshed, M. (2007). How the world's best-performing school systems come out on top. Retrieved November 23, 2018, from https://www.mckinsey.com/industries/social-sector/ our-insights/how-the-worlds-best-performing-school-systems-come-out-on-top.

Commission for Education Reform. (1995). Education reform for establishing new education system leading globalization and informatization. Seoul: Commission for Education Reform.

Cuban, L. (1988). Constancy and change in schools (1880s to the present). In P. W. Jackson (Ed.), Contributing to educational change: Perspectives on policy and practice (pp. 85-105). Berkeley, CA: McCutchan.

Cuban, L. (2013). Why so many structural changes in schools and so little reform in teaching practice? Journal of Educational Administration, 51, 109-125.

Fernandez, T., Ritchie, G., \& Barker, M. (2008). A sociocultural analysis of mandated curriculum change: The implementation of a new senior physics curriculum in New Zealand schools. Journal of Curriculum Studies, 40(2), 187-213.

Fullan, M. (1994). Coordinating top-down and bottom-up strategies for education reform. In R. Anson (Ed.), Systemic reform: Perspective on personalizing education (pp. 7-23). Washington, DC: U.S. Department of Education.

Fullan, M. (2007). The new meaning of educational change (4th ed.). New York, NY: Teachers College Press.

Gim, C. (2002). A critical examination of the Korean national curriculum research and development system. The Journal of Curriculum Studies, 20(3), 77-97.

Gim, C. (2011). A critique of the policy discourse of school-based curriculum autonomy in Korea. The Journal of Curriculum Studies, 29(4), 47-68.

Goodson, I. (1994). Studying curriculum: Cases and methods. London: Teachers College Press.

Grimaldi, E. (2012). Analysing policy in the context(s) of practice: A theoretical puzzle. Journal of Education Policy, 27(4), 445-465.

Hargreaves, A., \& Fullan, M. (2012). Professional capital: Transforming teaching in every school. New York, NY: Teachers College Press.

Hargreaves, A., Lieberman, A., Fullan, M., \& Hopkins, D. (Eds.). (2009). Second international handbook of educational change. Dordrecht: Springer. 
Hilferty, F. (2008). Theorising teacher professionalism as an enacted discourse of power. British Journal of Sociology of Education, 29(2), 161-173.

Hong, W. (2011). Policy efforts for autonomous and diversified school curriculum: Paradoxical results and potential alternatives. The Journal of Curriculum Studies, 29(2), 23-43.

Hwang, B. (2015). Education and nation-building. In S. Oh et al. (Eds.), 70 years of Korean education (pp. 305-360). Seoul: National Museum of Korean Contemporary History.

Jeong, K. (2006). A narrative inquiry on two teachers' experiences of the practical process of integrated subject matters' implementation in elementary school. The Journal of Curriculum Studies, 24(3), 125-146.

Jeong, Y., \& Lee, K. (2011). Study on teachers' acceptance of curriculum autonomy policies. The Journal of Curriculum Studies, 29(3), 93-119.

Kim, B. (2007). The hermeneutical reconceptualizing of curriculum and teaching-learning process. The Journal of Curriculum Studies, 25(4), 61-80.

Leana, C. R. (2011). The missing LINK in school reform. Stanford Social Innovation Review, 9(4), 30-35.

Lieberman, A., \& Pointer Mace, D. (2008). Teacher learning: The key to education reform. Journal of Teacher Education, 59(3), 226-234.

Masuda, A. (2010). The teacher study group as a space for agency in an era of accountability and compliance. Teacher Development, 14(4), 467-481.

McCluskey, N. (2010). Behind the curtain: Assessing the case for national curriculum standards. Policy Analysis, 661. Retrieved November 23, 2018, from http://ssrn.com/abstract=1572589.

Ministry of Education. (1992). The general guideline of the national curriculum. Seoul: Ministry of Education.

Ministry of Education. (2013a). The basic plan for national achievement assessment in 2013. Seoul: Ministry of Education.

Ministry of Education. (2013b). The basic plan for exam-free semester in secondary schools. Seoul: Ministry of Education.

Ministry of Education, Science, and Technology. (2009). The general guideline of the national curriculum. Seoul: Ministry of Education, Science, and Technology.

OECD. (2005). Teachers matter: Attracting, developing and retaining effective teachers. Paris: OECD.

OECD. (2011). Education and skills. In OECD (Ed.), How's life? Measuring well-being (pp. 145-168). Paris: OECD. Retrieved November 23, 2018, from doi:https://doi. org/10.1787/9789264121164-9-en.

Park, M. (2007). A narrative inquiry into elementary teachers' implementation of the integrated curriculum: Based on three teachers' stories. The Journal of Curriculum Studies, 25(1), 69-93.

Park, H. (2015). The scale and characteristics of school education expansion after liberation. In S. Oh (Ed.), 70 years of Korean education (pp. 121-187). Seoul: National Museum of Korean Contemporary History.

Park, J., Park, C., Seo, H., \& Youm, Y. (2010). Collection of Korean child Well-being index and its international comparison with other OECD countries. Korean Journal of Sociology, 44(2), $121-154$.

Pietarinen, J., Pyhältö, K., \& Soini, T. (2017). Large-scale curriculum reform in Finland: Exploring the interrelation between implementation strategy, the function of the reform, and curriculum coherence. The Curriculum Journal, 28(1), 22-40.

Popkewitz, T. (1991). A political sociology of educational reform: Power/knowledge in teaching, teacher education, and research. New York, NY: Teachers College Press.

Priestley, M. (2011). Whatever happened to curriculum theory? Critical realism and curriculum change. Pedagogy, Culture and Society, 19, 221-238.

Priestley, M., \& Biesta, G. (2013). Introduction: The new curriculum. In M. Priestley \& G. Biesta (Eds.), Reinventing the curriculum: New trends in curriculum policy and practice (pp. 1-12). London: Bloomsbury Academic. 
Priestley, M., Edwards, R., Priestley, A., \& Miller, K. (2012). Teacher agency in curriculum making: Agents of change and spaces for manoeuvre. Curriculum Inquiry, 42(2), 191-214.

Priestley, M., Biesta, G., Philippou, S., \& Robinson, S. (2015). The teacher and the curriculum: Exploring teacher agency. In D. Wyse, L. Hayward, \& J. Pandya (Eds.), The SAGE handbook of curriculum, pedagogy and assessment. London: SAGE Publication Ltd.

Ramberg, M. R. (2014). What makes reform work? School-based conditions as predictors of teachers' changing practice after a national curriculum reform. International Education Studies, 7(6), 46-65.

Shin, S., Kwak, B., \& Kim, J. (1981). Research and development of general guideline of the national curriculum. Seoul: Korean Educational Development Institute.

Sinnema, C., \& Aitken, G. (2013). Emerging international trends in curriculum. In M. Priestley \& G. Biesta (Eds.), Reinventing the curriculum: New trends in curriculum policy and practice (pp. 141-163). London: Bloomsbury Academic.

Sloan, K. (2006). Teacher identity and agency in school worlds: Beyond the all-good/all-bad discourse on accountability-explicit curriculum policies. Curriculum Inquiry, 36(2), 119-152.

So, K. (2013). Issues of national curriculum revision: From a view of a general guideline researcher. Education Research and Practice, 79, 87-100.

So, K. (2017). Understanding curriculum. Paju: Kyoyookkwahaksa.

So, K., \& Choi, Y. (2018). Understanding teachers' practices in the context of school-based educational reform: Focusing on the concept of 'teacher agency'. The Journal of Curriculum Studies, 36(1), 91-112.

So, K., \& Kang, J. (2014a). Curriculum reform in Korea: Issues and challenges for twenty-first century learning. The Asia-Pacific Education Researcher, 23(4), 795-803.

So, K., \& Kang, J. (2014b). Conflicting discourses on content reduction in South Korea's national curriculum. International Education Studies, 7(11), 10-18.

So, K., Kim, J., \& Lee, S. (2012). The formation of the south Korean identity through national curriculum in the south Korean historical context: Conflicts and challenges. International Journal of Educational Development, 32(6), 797-804.

Spillane, J. (1999). External reform efforts and teachers' initiatives to reconstruct their practice: The mediating role of teachers' zones of enactment. Journal of Curriculum Studies, 31, $143-175$.

Taylor, M. W. (2013). Replacing the 'teacher-proof' curriculum with the 'curriculum-proof' teacher: Toward more effective interactions with mathematics textbooks. Journal of Curriculum Studies, 45, 295-321.

Tyack, D. (1991). Public school reform: Policy talk and institutional practice. American Journal of Education, 100(1), 1-19.

Tyack, D., \& Cuban, L. (1995). Tinkering toward utopia: A century of public school reform. Cambridge, MA: Harvard University Press.

Weick, K. E., Sutcliffe, K. M., \& Obstfeld, D. (2005). Organizing and the process of sensemaking. Organization Science, 16(4), 409-421.

Zhao, Y. (2009). Comments on the common core standards initiative. AASA Journal of Scholarship and Practice, 6(3), 46-54.

Kyunghee So is a professor in the Department of Education at Seoul National University, Seoul, South Korea. Her research focuses on the formation and development of national curriculum, teachers' knowledge construction and identity, and competency-based curriculum reform. She has directly participated in developing national curriculum that has been revised frequently, contributing to forming critical discourse in the national curriculum system of South Korea. She is interested in promoting school systems that can consider students' diverse backgrounds and teachers' agency in curriculum management. Notably, she introduced the international trends in competency-based curriculum to South Korea, leading Korean educators and policymakers to come up 
with alternative ideas that can escape from subject-centered curriculum. Currently, she is conducting a project about understanding teacher agency in the context of school-based educational reform. Using qualitative methods, the project examines in depth how teachers deal with the context of recent educational reform in which they are asked to become agents of change. E-mail: sohee@snu.ac.kr.

Open Access This chapter is licensed under the terms of the Creative Commons Attribution 4.0 International License (http://creativecommons.org/licenses/by/4.0/), which permits use, sharing, adaptation, distribution and reproduction in any medium or format, as long as you give appropriate credit to the original author(s) and the source, provide a link to the Creative Commons licence and indicate if changes were made.

The images or other third party material in this chapter are included in the chapter's Creative Commons licence, unless indicated otherwise in a credit line to the material. If material is not included in the chapter's Creative Commons licence and your intended use is not permitted by statutory regulation or exceeds the permitted use, you will need to obtain permission directly from the copyright holder.

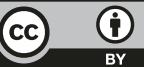

